\title{
Study for Mongyu Dowondo - Dream Journey to the Peach Blossom Land - in the Perspective of the Unconscious: Centering on Dream Interpretation of Prince An Pyeong
}

\author{
Hyun Kwon Lee ${ }^{1}$ and Hye Ri Yoon ${ }^{2}$ \\ ${ }^{1}$ Hyun Kwon Lee Psychoanalytic Office, Seoul, Korea \\ ${ }^{2}$ Hye Ri Yoon Psychiatric Clinic, Seoul, Korea
}

\author{
무의식적 관점에서 본 몽유도원도: 안평대군의 꿈 분석을 중심으로 \\ 이현권 ${ }^{1} \cdot$ 윤혜리 ${ }^{2}$ \\ ${ }^{1}$ 이현권 정신분석 연구소, ${ }^{2}$ 윤혜리 정신건강의학과의원
}

This is the first study analyzing Prince An Pyeong's dream, the main character of "Dream Journey to the Peach Blossom Land (henceforth abbreviated $<$ Dream Journey $>$ ), " which is the most important milestone in the history of Korean painting, from a psychoanalytic perspective. According to the analysis of Prince An Pyeong's $<$ Dream Journey $>$, which is based on Tao Yuanming's $<$ The Peach Blossom Spring>, a representative poet of China's Jin(晉) Dynasty, "Prince An-pyeong wishes for a world of father object with a mother object." Utopia for An Pyeong was an unconscious fantasy that repeatedly emerged at the end of King Sejong's reign, and his life's direction was to follow his father's will and protect the eldest son's succession as desired by the father. Based on the foregoing analysis, the author concluded that in the Korean utopia, King Sejong's space as an important object, was unconsciously progressing and how the unconscious contents-latent dream-affected the artistic form.

Psychoanalysis 2021;32(4):127-141

Keywords: Dream Journey to the Peach Blossom Land; Prince An Pyeong; Artist An Gyeon; Dream Interpretation; The Unconscious.

Received: August 24, 2021 Revised: September 14, 2021 Accepted: September 14, 2021

Address for correspondence: Hyun Kwon Lee, MD

Hyun Kwon Lee Psychoanalytic Office, 27 Guuigangbyeon-ro, Gwangjin-gu, Seoul 05115, Korea

Tel: +82-2-2138-7588, Fax: +82-2-2138-7589, E-mail: treeself@hanmail.net

서 론

몽유도원도(夢遊桃源圖)(Figure 1)는 세종29년(1447년)에 그의 셋째 아들 안평대군(安平大君)의 꿈을 화가인 안견(安 堅)이 그린 것이다. 제목에서 암시하듯, 몽유도원도는 중국 진(晉)나라의 시인 도연명(陶淵明)의 작품 도화원기(桃花源 ㅎ⼰)와 유사한 내용으로, 현재는 일본 덴리(天理) 대학 중앙 도서관에 소장되어 있다. 안견은 조선뿐만 아니라 한국 미술

This is an Open Access article distributed under the terms of the Creative Commons Attribution Non-Commercial License (https://creativecommons.org/licenses/by-nc/4.0) which permits unrestricted non-commercial use, distribution, and reproduction in any medium, provided the original work is properly cited.
사에서 가장 대표적인 위치를 차지하는 화가로, 이 몽유도원 도는 그의 남아있는 유일한 진품으로 알려져 있다(An 2009). 동양의 이상향인 도원(桃源)에 대한 끊임없는 관심으로 우리 나라뿐만 아니라 중국도 당나라때부터 송, 원, 명, 청을 거치 며 많은 대가의 손을 거쳐 그려왔지만 오늘날 남아 있는 가장 오래된 회화는 안견의 몽유도원도로 알려져 있다(Kim 2002).

세종32년의 시대는 조선의 역사에서 중흥의 시기였다. 후 대에게 '해동의 요순(堯舜)'으로 불렸던 것처럼 세종은 조선 의 황금기, 르네상스를 이끌었던 성군이었다. 건국의 새로운 통치 이념인 성리학이 뿌리내리면서 정치, 경제, 과학, 문화 등 전 분야에서 국가의 발전을 이끌었다. 1446년(세종28)에 그의 천재성과 애민 정신의 결정판인 훈민정음을 반포하였 


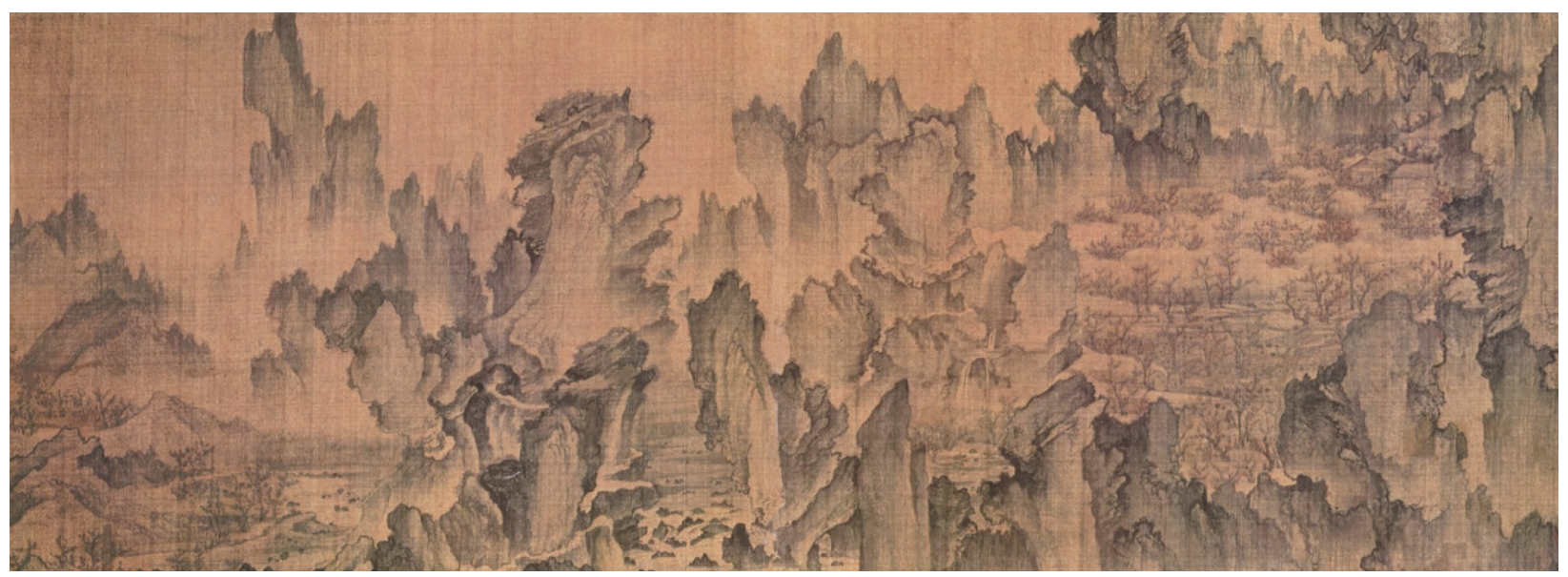

Figure 1. Mongyu Dowondo (1447), $38.7 \times 106.1 \mathrm{~cm}$, Tenri Central Library, Janpan.

고(Han 2019), 다음 해 정묘년에 선대 왕의 선업을 예찬한 용비어천가의 간행은 전성기의 정점을 말하는 듯하다(Kim 2002). 세종의 존재감은 이에 그치지 않는다. 조선의 후대 왕 들은 세종을 모범으로 왕조를 중흥시키려 했으며, 조선의 두 번째 전성기를 이끌었던 정조 역시 세종의 정책을 기반으로 하였다(Han 2019). 이는 과거의 이야기가 아닌 것이, 현재 역시 한국인이 가장 사랑하고 존경하는 역사적 위인은 바로 세종이며, 서울의 세종대로 중심에 앉아있는 세종대왕의 모 습은 그 상징일 것이다.

안평대군은 아버지 시대의 핵심 문신을 이끌고 시단(詩 壇)과 예단(藝壇)을 구축하여 시서화(詩書畫) 문예를 선도하 였고, 세종조 르네상스의 한 축을 담당하였다(An 2009; Kim 2002). 안평은 20 세에 이미 시, 서, 화 삼절(三絕)의 경지에 올랐으며, 그의 서예는 당대 최고의 수준으로 중국의 조맹부 체를 기원으로 하나 그 이상의 실력으로 명나라에 널리 알 려졌다(Sim 2018).

안견 역시 조선 문화 중흥기에 걸맞은 화가였다. 그는 세종 조가 배출한 가장 훌륭한 화원이었으며, 그 영향력은 우리나 라 회화사상 제일 컸다고 한다(An 2009). 비록 도화원 화원 출 신이라 그의 구체적인 삶은 알려져 있지 않지만, 신분제를 뛰 어넘어 정4품까지 올랐다는 사실은 그의 위상을 짐작하게 한 다. 그는 당대 최고의 서화 수집가인 안평대군의 신임을 받았 고, 서로 깊은 친분을 유지한 것으로 알려져 있다(Kim 2002).

몽유도원도는 이러한 찬란한 조선 초기 문예를 품은 집약 체이다. 문화를 이끌었던 안평의 최고 수준의 제기(提起)와 서예, 우리나라 역사상 가장 뛰어난 화가라고 일컬어진 안견 의 그림, 그리고 정인지, 김종서, 박팽년, 성삼문, 이개, 신숙 주 등 당대 최고의 문신인 21 명의 시문의 조합은 그야말로 시, 서, 화 삼절의 경지를 구현한 작품이다. 그러므로 하나의 뛰어난 미술작품일 뿐만 아니라 세종조의 문화의 성격과 수
준을 복합적으로 말해 주는 문화적 업적인 동시에 한 시대의 역사적 현상을 대변하는 막중한 사료인 것이다(An 2009).

하지만 안평대군의 삶은 평탄하지 않았다. 황금시대인 세 종조가 저물면서 왕세자 문종은 지병으로 젊은 나이에 죽어 왕위가 불안정했으며, 그의 아들인 단종은 험한 정치적인 환 경을 견디기에는 너무 어렸다. 이러한 분위기에서 수양대군 (후에 세조)은 계유정란(1453)을 통해 안평대군 및 여러 공신 들을 모반이라는 죄목으로 죽였고, 이후 사육신 사건(1456)으 로 세종조를 이끌던 뛰어난 문신들을 죽임으로써 절정기의 세종조 문화의 수준은 이후 상당기간 회복되지 못했다(An 2009). 그의 형에 의해 잔인한 권력의 희생양이 된 안평대군 은 이후 역사에서 그가 이룬 예술적인 업적과 함께 흔적없이 사라졌다. ${ }^{a}$ 그의 이름조차 거론할 수 없는 긴 시기가 지나 숙종 (1661-1720)때 왕족의 가계보에 복권되었고, 영조(1724-1776) 시기에 시호가 내리고 제사를 재개하였다. 정조(1776-1800) 는 사면된 충신 32명을 '충신지위(忠臣之位)'라 칭하고, 여기 에 안평대군을 제일 앞에 모셨다(Kim 2002). 정조가 세종의 정책을 적극 반영하여 제 2의 조선 문화 중흥기를 이끌었다 는 점과 그 시기 안평의 위치가 반역의 수괴에서 제 1 의 충신으 로 변화했음이 의미심장하다. 이러한 안평대군의 운명처럼 몽유도원도 역시 사라질 뺀했지만 기적적으로 살아남아 여러 곳 을 유랑하다가 1929년 일본 월간지 〈동양미술〉 9월호에 그 존 재를 알렸으며(Kim 2002), 여러 미스터리를 남긴 채 앞서 말했 듯 현재 일본 덴리(天理) 대학 중앙 도서관에 소장되어 있다.

몽유도원도는 그 사연만큼 다양한 맥락에서 연구가 이루 어졌다. 저자는 몽유도원도의 연구가 큰 틀에서 안견을 중심

a이러한 역사적 배경으로 안평대군에 대한 기록은 〈단종실록〉 이후 왜곡되었다는 것이 역사가들의 의견이다. 실록에 편수자의 이름을 남기지 않은 것이 〈단종실록〉이 유일할 정도로 안평대군에 대한 기 록을 날조하거나 재편성하였다(Sim 2018). 


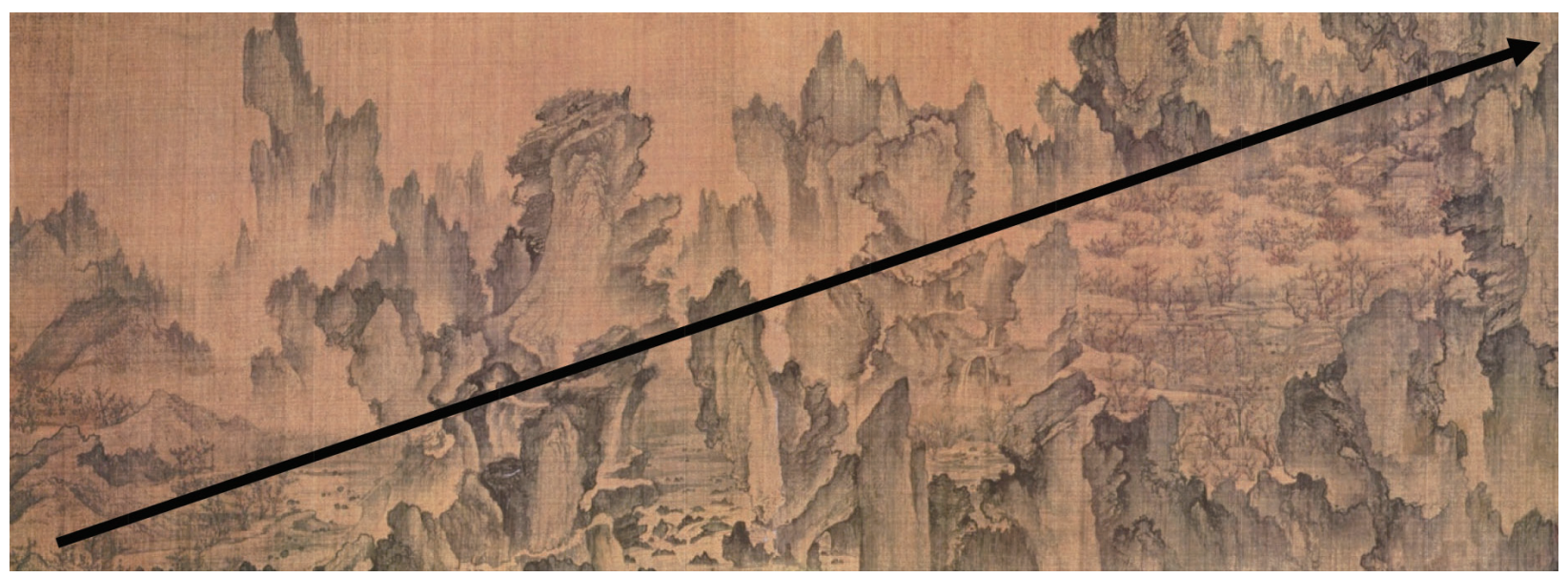

Figure 2. Mongyu Dowondo: conventional direction of narrative.

으로 한 몽유도원도의 미술사적 관점과 안평대군이라는 인 물에 대한 역사적 연구로 나뉜다고 생각한다. 한국 미술사적 관점으로는 미술사학자인 안휘준을 중심으로 주로 연구가 이루어졌으며(An 2009; Cho 2015), 안평에 대한 심도 있는 저작으로는 심경호의 책이 최근 간행되었다( $\operatorname{Sim} 2018)$. 또 한 안평대군의 사회문화적인 상황과 개인의 삶을 몽유도원 도와 연결시킨 흥미로운 저작도 있다(Kim 2002). 하지만 몽 유도원도 회화의 시작점이 바로 안평대군의 꿈이라고 볼 때, 그의 꿈 분석은 몽유도원도 분석에서 가장 핵심적인 역할을 할 것이라 짐작한다. 비록 서구에서 연구가 시작되었지만 Freud로부터 시작된 정신분석의 경험은 안평의 꿈을 가장 심도있게 이해할 수 있는 가능성을 시사한다. 따라서 저자는 여러 한계가 있을 것이라 예상하지만 무의식적 관점으로 안 평대군의 꿈 분석을 시도할 것이다.

저자의 꿈 분석 방법은 Freud의 임상 및 예술 분석과 다르 지 않다(Freud 1900, 1910). 저자는 여러 어려움과 제한점이 있으나 실제 임상에서 이루어지는 방법을 적용하여 안평대 군의 꿈을 분석하려 하였다. 역사적 인물과 실제 환자와의 차이는 현존하는 사료의 분석 및 관련 신화나 설화, 시대 관 념, 종교 등을 통해 보완하였다. 특히 안견이 몽유도원도를 그린 후 안평대군은 자신의 꿈의 자세한 내용과 관련해 몇 가지 연상을 도원기(桃源記)에 남겼으며, 3 년 뒤에 이 꿈이 여전히 자신의 삶에 영향을 준다는 글을 적어 놓은 점은 분 석에 도움을 주었다. 또한 실제 임상에서 확인하듯, 해석되 지 않는 꿈이나 전이는 일상생활에서 반복되므로, 안평의 전 반적인 삶의 지향점을 살펴봄으로써 꿈 해석에 대한 또 다 른 근거를 제시할 것이다.

저자의 시도는 몇 가지 의미있는 사항을 기대하게 한다. 첫째, 중국적 이상향인 도원과 다른 조선 이상향의 발견을 기대할 수 있을 것이다. 뒤에 자세히 기술하겠지만 안평의
도원기는 비록 시대적 상황으로 인해 중국 도원의 그늘에 있지만 여러 차이점이 있다. 둘째, 미술사가들이 말하는 몽 유도원도에 대한 특징적인 양식에 대하여 설명할 수 있을 것이다. 당시 동아시아 회화 전통과는 다르게 (꿈에도 있는) 사람이 그림에 없고, 두루마리 그림이 지켜왔던 방식-이야 기가 오른쪽에서 왼쪽으로 전개-이 몽유도원도는 그와 반 대로 왼편 하단부에서 시작하여 오른편 상단부로 이야기가 이어지고 있다는 점이다(Figure 2) (An 2009). 저자가 이전 논 문에서 밝히고 주장했듯이, 양식(form/style)의 변화는 내용 (contents)의 변화가 선행한다(Lee와 Yoon 2021a; 2021b). 이 내용은 꿈을 비롯한 무의식적 환상이 중요한 역할을 하므로 안평대군의 꿈의 내용이 기존 양식의 변화를 이끄는 힘이 되지 않을까 기대를 할 수 있다.

\section{본 문}

1

'몽유도원도시화권'은 상하 2개의 두루마리로 표구되어 있다. 전체적인 구성은 그림이 완성된 지 3년 후에 지은 제첨 (題簽)인 안평대군의 칠언절구가 있고, 안견의 그림인 도원 도(桃源圖)가 이어진다. 그림 뒤에 그림에 대한 설명인 안평 대군의 ‘도원기(桃源記)'가 있고, 뒤이어 21명의 제찬 시문이 실려있다.

도원기는 그림을 그리게 된 이유와 배경, 꿈의 자세한 내 용, 이와 연관된 연상 등을 비교적 상세하게 적었다. 원문은 한문으로, 본 논문은 분석의 필요성으로 좀 길긴 하지만 한 글로 번역된 전문을 적어보기로 하겠다(Sim 2018). ${ }^{b}$

${ }^{\mathrm{b}}\langle$ 인용문 $1>$ 은 분석의 편의를 위해 내용을 저자의 자의로 3 개로 나 누었고, 명확한 설명이나 분석이 필요한 단어나 어구, 문장은 한문 을 첨가하였다. 


\section{〈인용문 1〉}

1) 정묘년(1447년) 4월 20일 밤, 자리에 눕자마자 정신이 아 른아른하여 깊은 잠에 들어 꿈을 꾸게 되었다.

인수(仁叟, 박팽년)와 더불어 어느 산 아래에 당도하니, 층층 멧부리가 우뚝 솟아있고, 깊은 골짜기가 그윽하고 조촐하며 복숭 아나무 수십 그루가 있었다. 희미한 오솔길이 숲 밖에 다다르자 갈라졌음으로 서성대며 어디로 가야 할지 몰랐다. 한 사람을 만 났는데, 산관야복(山冠野服)으로 길게 읍례하며 나한테 이르기를 "이 길을 따라 북쪽으로 굽어 들어 골짜기로 들어가면 도원이외 다"라고 했다.

2) 내가 인수와 함께 말에 채찍을 휘두르며 찾아가니, 산벼랑 이 울뚝불뚝하고 나무숲이 빽빽하며 계속 물은 돌고 돌아 거의 일백 굽이나 휘어져 나가 사람을 홀리게 한다. 골짜기에 들어가 자 동구가 드넓게 트여서 사방 2, 3리쯤 될 듯했다. 사방에는 산 이 바람벽처럼 높이 솟아있고 구름과 안개가 자욱한데, 멀고 가 까이의 도화 숲이 어리비치어 붉은 아지랑이가 떠올랐다. 또 대 나무 숲과 초가집이 있는데, 사립문은 반쯤 닫히고(柴扁半閉), 흙 담은 이미 무너졌으며(土砌已沉), 닭과 개와 소와 말은 없었다. 앞 시내에는 조각배 하나가 물결 따라 오락가락했다. 그 정경이 소조하여(쓸쓸하여) 선부(신선 거처)와 같았다.

이에 서성이며 오래도록 둘러보고는, 인수에게 이르기를 "한유 (韓愈)가 바위에다 걸침목을 걸치고 골짜기를 뜷어 집을 지었다 고 한 것은 이를 두고 이른 것이 아니겠는가? 정말 여기가 도원 동(桃源洞)이다"라고 했다.

곁에 두어 사람이 있었으니, 바로 최항, 신숙주 등으로 함께 찬 운(撰韻)을 하는 자들이다. 모두 짚신감발을 하고 오르내리며 실 컷 구경하다가 문득 잠에서 깨었다.

3) 아! 사방으로 길이 통하는 큰 도회지는 참으로 화려하고 이 름난 벼슬아치들이 노니는 곳이요, 깎아지른 절벽과 외진 골짜기 는 조용히 숨어 사는 은자들의 거처이다. 몸에 화려한 관복을 걸
친 자들은 발자취가 깊은 산림에 미치지 않고, 바위와 샘물 등 자 연에 정을 둔 사람들은 꿈에도 대궐 조정을 바라지 않는다. 고요 함과 시끄러움은 본디 길이 다르니, 이는 자연스러운 이치라 하 겠다.

옛사람은 말하기를, '낮에 한 일이 밤에 꿈이 된다'라고 했다. 하지만 나는 궁중에 몸을 담아 밤낮으로 하는 일이 많은데 어째서 꿈이 산림에까지 이르렀던가? 또 갔더라도 어떻게 도원에 이르렀 더란 말인가? 또 좋아하는 사람이 많거늘 도원에 노닐면서 하필 이면 이 몇 사람만 따르게 되었던가? 그것은 내 성품이 고요하고 외딴곳을 좋아하며 평소 자연을 그리는 마음을 품고 있던 데다가, 이 몇 사람과의 사귐이 한층 두터운 까닭에 그런 것이리라.

그리하여 가도(可度, 안견)에게 명하여 내 꿈을 그림으로 그리 게 했다. 다만 옛날부터 일러오는 도원이라는 곳이 진정 이것과 같았을지는 모르겠다. 뒷날 관람자가 옛 그림을 구해서 나의 꿈 과 비교해본다면 반드시 무어라 할 말이 있을 것이리라.

꿈을 꾼 지 사흘째, 그림이 완성되었다 비해당(匪懈堂) 매죽헌 (梅竹軒)에서 쓴다.

이 도원기는 안견이 그림을 완성한 뒤에 작성한 것이다. 아무리 안견과 안평대군의 관계가 좋을지라도 개인의 꿈을 그리는 것은 왕인 세종의 허락을 받아야 가능했고, 안견은 안평대군의 요구를 받아들여야 할 위치였다. 안평대군은 안 견에게 그림 그리는 전 과정을 함께하며 완성했을 것으로 여겨지고 있다(Kim 2002). 안견의 그림(Figure 2)의 방향은 안평의 발현몽(manifest dream)〈인용문 1-1), 2)〉의 내러티 브의 방향대로 그려졌으며, 이는 전술한 대로 전통의 방식과 는 반대 방향이다. 이러한 내러티브는 대체로 충실하게 회화 에 반영되었고, 저자는 $\mathrm{An}$ (2009)의 구분 방식에 따라 회화 를 네 개의 경군(景群)으로 나누었다(Figure 3). Figure 3에 서 1군은 어디서나 볼 수 있는 평범한 야산으로 도원으로 들

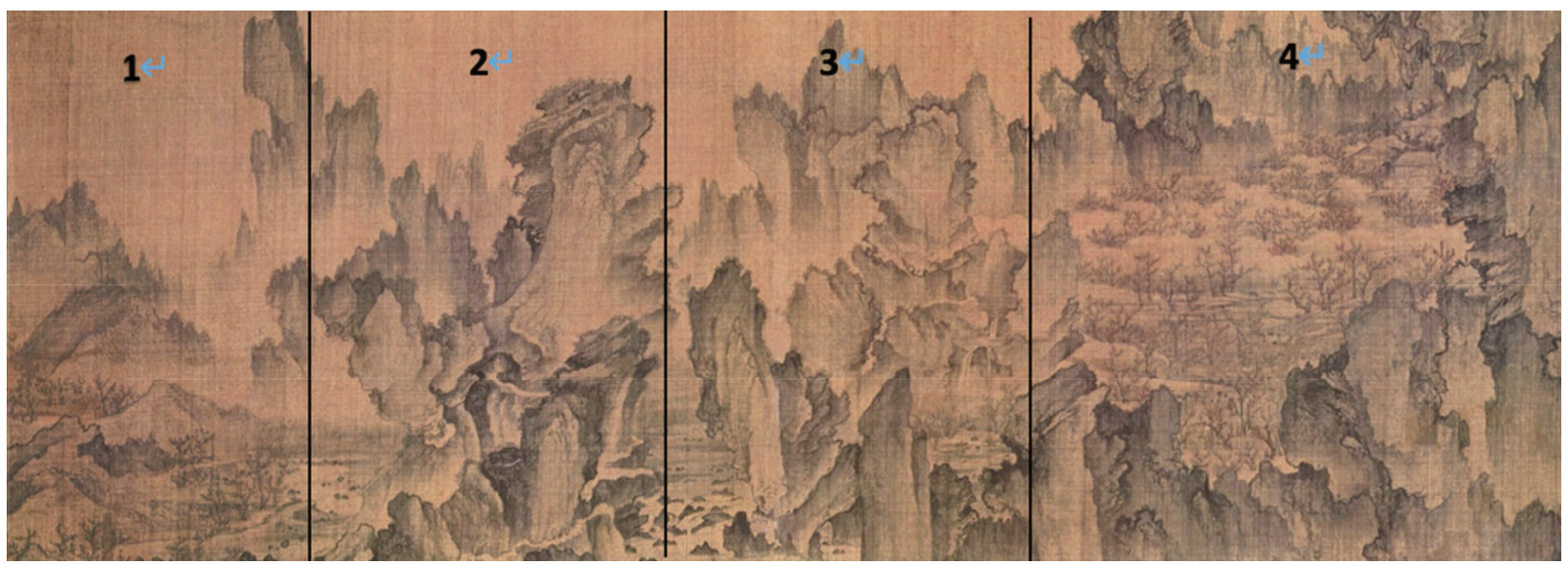

Figure 3. Mongyu Dowondo: four scenic distinctions. 
어가기 전의 세계를 의미한다. 하단부의 길 주변에 복숭아나 무들이 보이며, 2군에서 하나의 길은 기암절벽의 산으로 들 어가는 입구로 보인다. 표구를 할 때에 사변이 잘려나간 것 으로 예상되기 때문에 2군의 하단에는 두 갈래의 길이 더 분 명하게 보일 것으로 예상된다(An 2009). 아마도 그곳에서 산 관야복(山冠野服)의 사람을 만나 안내를 받았을 것이다. 2군 과 3 군은 도원으로 들어가기 전의 경험을 묘사하였다. 1 군의 산과 다르게 2군의 산들은 기괴하고 비현실적인 형상의 산 들로 가득 차 있다. 3 군은 도원 입구를 나타내듯, 2 군에서 사 라진 길이 나타나 소라 껍질 같은 납작한 산 밑을 돌아 자취 를 감추며 시선을 옆의 넓은 도원으로 이끈다. 4군은 도원의 경치를 묘사한 것으로 사방이 산으로 싸여있어 하나의 동굴 (도원동, 桃源洞)임을 시사한다. 복숭아 꽃은 빨간색, 연분홍 색으로 표현되어 있고, 꽃심은 노랑색과 금채로 묘사되었음 이 짐작되어 파랑, 초록, 연초록으로 그려져 있는 잎과 어울 려 영롱한 분위를 자아낸다(Figure 4) (An 2009).

이렇게 안평대군 꿈의 내러티브를 대체로 충실히 구현했 지만, 회화와 〈인용문 1)과 뚜렷하게 다른 점이 있다. 첫째, 사람이 보이지 않는다. 꿈의 주인공인 안평대군과 초반부부 터 동행했던 박팽년, 그리고 뒤에 나타나 한바탕 뛰어놀았던
최항과 신숙주 뿐만 아니라, 길을 안내했던 산관야복의 사람 도 보이지 않는다. 둘째, 꿈의 내용 중, '사립문은 반쯤 닫히고 (柴府牛閉), 흙담은 이미 무너졌으며(土砌已沉), 닭과 개와 소 와 말은 없었다'의 회화적 표현이 불명확하다(Figure 4). 이러 한 차이점들은 의식/무의식적 역동의 가능성을 말하는 것으 로 뒤에 시도할 분석에 중요한 재료가 될 것임을 시사한다.

도연명(도잠 陶潛 365-427)의 도화원기(桃花源記)는 안평 대군의 도원기의 전범(典範)이다. 이는 전반적인 내용과 구 조의 유사함 뿐만 아니라, 꿈의 내러티브나 꿈을 깬 후에도 ‘도원'은 중심 주제로 영향을 주기 때문이다. 실제로 도원은 도연명의 창작 이후 중국 역사에서 시대적인 관념이나 사상 의 영향을 받았지만 그 시대의 이상향을 상징하는 공간으로 일관적으로 인지되었고, 이에 대하여 많은 문사나 화가들은 이를 중요한 주제나 소재로 다루었다(Kim 2002). 한국에서 는 12 세기 고려시대에 도원에 대한 기록이 있으며, 현실을 중시하는 성리학의 학풍에도 문인들의 가슴에 굳게 자리했 었다(An 2009). 따라서 안평대군의 도원기를 이해하는데 있 어서, 도연명의 도화원기가 중요한 틀이 되므로 원문을 인용 하여 실었다(An 2009).

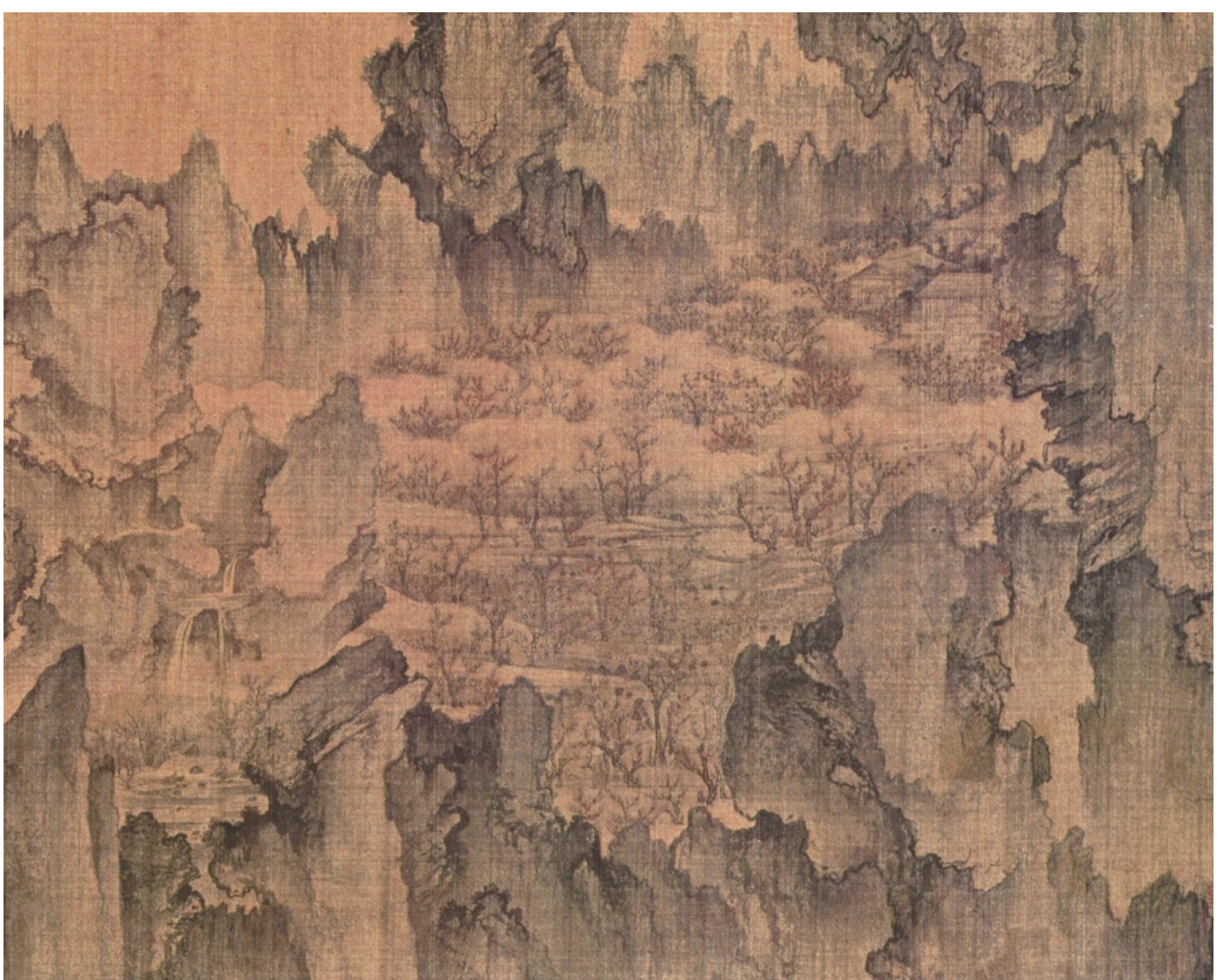

Figure 4. Part of Mongyu Dowondo: cherry blossom land. 


\section{〈인용문 2〉}

동진(東晉)의 태원 연간(太元年間 376-396)에 무릉(武陵)의 어떤 사람이 고기를 잡아 생활을 했는데 (어느 날) 내를 따라가다 가 길을 잃게 되었다. (이때) 갑자기 복숭아 꽃나무 숲을 만났다. 냇물의 좌우 양안(兩岸) 수백 보에 걸쳐 (복숭아 나무 이외에는) 잡나무가 (일체) 없고 향기로운 풀들만이 산뜻하고 아름다우며 떨어지는 꽃잎들이 펄펄 날리고 있었다.

어부가 이것을 매우 이상히 여기며 다시 앞으로 나아가 그 복 사꽃 숲이 끝나는 곳까지 가보고자 하였다. 숲이 다 하는 곳에 물 이 흐르고 문득 산 하나가 나타났다. 산에는 조그마한 구멍이 있 는데 마치 빛이 있는 듯하였다. 곧 배를 버리고 구멍을 따라 들어 갔다. 처음은 아주 좁아서 사람이 겨우 들어갈 수 있을 정도였다. 다시 수십 보를 가니 확 똟리며 밝아졌다. 땅은 평평하고 넓으며, 집들은 엄연하고, 좋은 밭과 예쁜 연못과 줄지은 뽕나무와 대나 무 등이 있었다. 깊은 사방으로 뜷려있고, 닭이 울고 개가 짖는 소리가 들렸다. 그 가운데 (사람들이) 왔다 갔다 하며 씨를 뿌리 고 농사를 짓고 있었다. 남녀의 옷 입는 것은 모두 사람들(세상 사람들)과 같았고, 노인이나 어린이들은 다같이 기쁘게 즐거워하 였다. 어부를 보고 크게 놀라 어떻게 왔는지 물었다. 갖추어 답하 니 당장에 초청하여 술을 빚고 닭을 잡아 식사를 대접하였다.

이 어부가 왔다는 애기를 듣고 마을 사람들이 모두 찾아와 캐 물었다. 그들 스스로 말하기를 "선세에 진(秦)나라 때의 난을 피 하여 처자와 읍인(ㄹ巴ㅅㅅ)들을 이끌고 이 절경에 와서 다시 나가지 않았소. (그래서) 드디어 바깥 사람들과 떨어지게 되고 말았소”라 고 말하면서 “요즘은 어떤 세상이오?"라고 묻는 것이었다. 한(漢) 나라가 있는 것도 모르고 위진(魏晉)은 말할 것도 없었다. 이 어 부가 일일이 들은 바를 말하니 모두들 놀라고 탄식하였다. 다른 사람들도 각기 다시 자기 집에 그를 끌고 가 모두 술과 음식을 내 었다. 여러 날 묵고 사양하며 떠났다. 이들 중에 어떤 사람이 말 하기를 “다른 사람들에게는 예기하지 마시오"라고 하였다. 밖으 로 나와 배를 찾아서 먼저 길을 오며 곳곳에 표시를 했다. 군(郡) 에 이르러 태수(太守)를 만나 이처럼 설명하였다. 태수는 곧 사람 을 보내 그를 따라 가서 표시한 바를 찾도록 했지만 다시 그 굴을 찾지 못했다. 하남성(河南省) 남양현(南陽縣)의 유자기(劉子䩀)는 고상한 선비였다. 이 이야기를 듣고 흔연히 가볼 계획을 세웠으 나 이루지 못하고 머지않아 병으로 죽었다. 그 후로는 마침내 그 길을 묻는 사람이 없었다.

이처럼 도연명의 도화원기와 안평의 도원기의 전반적인 내러티브 구조는 유사하지만 지엽적인 부분에서 몇 가지 차 이점이 보인다. 몇 가지 특징적인 부분을 말하면 다음과 같 다. 첫째, 내러티브를 이끄는 주인공이 도화원기는 어부지만 도원기는 안평 자신이다. 둘째, 도원의 발견이 도화원기에서
는 어부가 스스로 발견했지만 도원기에서는 산관야복의 사 람이 알려주었다. 셋째, 전자에서는 마을 사람과 가축들이 등장하지만, 후자에서는 사람들이 없고 '닭, 개, 소, 말이 없 었다'고 언급하였다. 또한 도화원기에서는 술과 음식으로 대 접하지만, 도원기에서는 박팽년, 최항, 성삼문과 함께 논다. 넷째, 전자의 도원은 유인하는 역할만을 하여 정작 도원 내 부에서는 도화에 대한 묘사는 없지만, 후자에서는 도원 내부 의 도화에 대한 묘사가 있다-몽유도원도에서는 도화원의 묘사가 중심을 이룬다(Figure 4)-. 위 몇 가지 차이점은 담 론에 존재하는 이야기인 도화원기와 안평의 무의식적 내러 티브와의 차이로 여겨지며, 이러한 차이의 지점은 실제 임상 의 꿈 해석에서 보이는 것처럼 안평대군의 은밀한 무의식적 역동이 내포될 가능성이 높다.

2

꿈을 꾸기 전 역사적 배경은 다음과 같다. 안평대군이 꿈 을 꾼 1447년 4월경은 앞서 잠시 언급했듯이 1446년 6월 훈 민정음 해례본이 출간되는 등 세종의 치세가 정점에 이른 시기였다. 하지만 실제로 30 년간의 세종의 절정기가 저무는 시점이기도 했다. 이전 해인 1446년 3월 세종이 아끼던 왕비 소헌왕후(昭憲王后)의 죽음은 영원할 것 같았던 세종시대의 균열을 의미한다. 물론 그 전해(1445년) 한 달 간격으로 다 섯째 아들 광평대군과 일곱째 아들 평원대군의 죽음 역시 그 흐름에 있지만, 당시 세종이 늙고 병들어감에 따라 후사 인 맏아들 문종이 그 뒤를 이어야 했음에도 문종 역시 건강 이 좋지 못해 불안한 요인이 가중되었던 것이다. 성리학을 국가의 기조로 삼았지만 유교 국가의 근본 원칙인 적장자 승계는 조선 건국 후 한번도 이루어지지 못했다. 이는 전대 왕들의 창업을 이어 수성(守成)의 대업을 맡은 세종에게 가 장 큰 과제였던 것이다. 1441년(세종 23년) 문종의 후손인 단종이 태어났지만 세자빈 권씨는 세손을 낳은 다음 날 산 욕으로 사망했다는 점에서 소헌왕후의 죽음은 혹시 병약한 왕세자(문종)가 죽었을 경우 수렴청정을 할 사람이 없다는 의미에서 위기의 징조로 여겨지는 것이다(Kim 2002). 1447 년 2월 세종은 자신의 죽음과 장례를 준비하였고, 한달 후 3 월 16일에는 왕세자(문종)에게 국사를 대폭 이양했다. 이러 한 왕세자의 섭정 체제는 장자 계승을 위한 조치인 것이다. 그해 3월 24일은 소헌왕후의 상제(喪祭)여서 왕자들은 상복 을 벗었고, 상제 해에 맞춰서 안평대군은 불교 경전의 하나 인 '묘법연화경'의 간행을 준비하였고, 수양대군은 석가의 일 대기를 요약한 '석보상절'을 집필 중이었다. 4월 5일에는 조 선 건국의 공덕을 찬양하고 수성의 어려움을 경계한 '용비어 천가'가 완성되었다. 4 월 10 일은 세종의 탄생일이었지만 전 
해 심한 흉작으로 축하 의식이 생략되었다(Kim 2002).

꿈을 꾸기 전 간단히 요약한 위 역사적 사실들은 안평대 군 삶의 위기와 전환점으로 이해되며 (의식/무의식적으로) 몇 가지 사항을 우선 짐작하게 한다.

1) 아버지이자 왕인 세종의 나라를 위해 애써왔던 안평대 군의 삶은 이제 아버지의 뜻에 따라 몸에 밴 권력의 자리에 서 물러나야 한다. 이는 세종이 그에게 비해당(匪解堂)이란 당호(堂號)를 내리고, 그의 형에게 수양대군이란 작호(爵號) 를 내린 이유이다.

2) 비록 왕자라는 공식적인 자리지만, 한 인간으로서 어머 니의 죽음을 경험하고 아버지 죽음을 대면해야되는 심적인 고통 역시 이해되어야 한다. 어머니인 소헌왕후의 인품으로 볼 때 어머니와의 관계가 좋았을 것으로 예상되며, ${ }^{\mathrm{d}}$ 아버지 세종 역시 안평과의 관계가 좋았다고 한다(Sim 2018; Kim 2002).

이러한 주요 대상과의 관계 위기나 삶의 변화는 그의 꿈 에 깊이 영향을 주었을거라 짐작된다. 따라서 그가 3 년 뒤 (1450년) 정월, 몽유도원도에 남긴 또 하나의 제첨 역시 그 러할 것이라 예상할 수 있다. 그 전문을 번역된 한글로 보면 다음과 같다( $\operatorname{Sim} 2018)$.

'비해(匪解)는 '게으름없이'의 의미로 세종은 중산보의 〈증민지시〉 와 송나라 유학자 장재의 〈서명〉을 인용하였다. 이 책들을 통한 당 호의 의미에 대해 Kim (2002)는 '마음을 지키고 천성을 길러 임금 한 사람만을 섬긴다'로 해석하였다. 수양대군의 수양은 중국의 유 명한 고사인 수양산에서 충절을 지킨 백이와 숙제의 고사를 떠오 르게 한다. 세종이 특히 이 두 아들에게 충절을 뜻하는 이름을 지 어준 이유는 현재 권력의 중심에 있는 두 아들이 그의 후계 문종이 나 손자 단종의 시대에서의 그들의 위치를 정해 준 것으로 이해한 다(Kim 2002).

d소헌왕후는 왕비가 된 시기에 아버지 심온이 영의정에 올랐으나 정치적 역모에 휩싸여 태종에 의해 사사되었다. 그러한 상황에도 흔들림없이 세종을 내조하여 세종이 왕후를 평생 애틋하게 여겼다 고 한다. 타계 후에 정인지가 쓴 인품을 논한 글은 다음과 같다. "왕 후가 인자하고 어질고 성스럽고 착한 것이 천성에서 나왔는데, 중 궁에 정위한 뒤로는 더욱 스스로 겸손하고 조심했다" ( $\operatorname{Sim} 2018)$. '예를 들면, 세종은 자녀들의 교육을 강조하면서, 옛사람이 말하기 를 '부자 사이에는 마땅히 날마다 친근하여야 한다'라며, 하루 3차 례 왕자들과 식사를 하였고, 식사 후 강론을 했다고 하며 이 시간을 매우 중요시 했다고 한다(Sim 2018). 세종은 안평을 매우 아껴 1442 년 비해의 당호를 내렸는데, 이는 뒤에 설명하겠지만 정치권력에서 의 배제의 의미도 있지만, 세종이 내린 이 사호는 안평대군이 세종 조 문예의 지도자로 등장하는 신호이고, 공인이며, 이때부터 안평 대군은 '비해당'이란 별당을 만들어, 위 명을 필명으로 당대의 문사 와 예술인을 불러 모아 세종조에 꽃피기 시작한 문화와 예술을 주 도해 나갔다고 한다(Kim 2002).
〈인용문 3〉

세간 어디에서 무릉도원으로 꿈꾸랴

야복(野服)과 산관(山冠) 차림이 아직도 완연하다.

그림으로 그린 일은 정녕 호사스럽기에

천년은 전하리라고 스스로 만족해하노라.

그림이 이루어진지 3년뒤 정월 초하루 밤 치지정(致知亭)에 있 으면서 펼쳐보고는 짓는다.

청지(淸之).

여기서 야복(野服)과 산관(山冠)은 도원기〈인용문 1〉에서 도원으로 길을 안내했던 산관야복(山冠野服)의 사람에 대한 다른 표현이다. 이 글에서 이 사람이 '아직도 완연하다'라는 표현은 이 꿈이 3년동안 백일몽(daydream)으로 지속되었음 을 시사한다. 이 시기 역시 안평대군에게 3년 전 꿈과 유사 한 삶의 위기가 있다. 1449년 세종은 위중하여 죽음을 앞두 고 있었으며, 실제 다음 해 1450년(세종 32년) 2월 17일 아버 지이자 위대한 왕인 세종은 숨을 거두게 된다.

3

위 요약된 내용을 통해 볼 때 안평대군의 도원기 꿈은 단 순한 일상의 꿈이 아니라 주요 대상과의 관계와 상실, 갈등, 그리고 이와 연관된 삶의 전환기에서 나타난 내러티브와 이 미지이다. 저자는 이 시기에 반복적으로 등장하는 인물인 '산관야복(山冠野服)의 사람'에 주목한다. 희미한 오솔길의 갈림길에서 ‘북쪽으로 가면 도원’이라는 길을 안내해 주었으 며, 3년 후까지 그 이미지가 눈에 선한 인물이다. 저자의 분 석으로 이 인물은 다의적 의미가 내포된 아버지 대상인 세 종에 대한 꿈의 표상으로 이해된다. 앞서 살펴보았듯, 안평 대군의 꿈과 백일몽은 모두 아버지 세종과 깊은 관련이 있 다. 도원기〈인용문 1〉의 꿈은 늙고 병약해진 세종이 국사를 문종에게 이양한 후였고, 3년 뒤의 백일몽〈인용문 3〉은 세 종의 죽음이 임박한 시기였다. 그럼 왜 아버지 대상이 안평 을 '도원'으로 안내했을까? 도연명의 도화원기는 정치 권력 이 배제된 폐쇄된 소규모의 공동체를 의미했지만, 이후 중국 사회의 변화에 따라, 종교나 사상에 따라 다소 변모하였다. 조선 초기 역시 중국의 이상향을 흡수하여 이해하였는데, 바 로 몽유도원도의 시문을 적은 문사들의 글로 이해할 수 있 다. 이는 세가지 유형으로 분류할 수 있는데 '도원'을 당나라 왕유(王維)처럼 선경(仙境)과 동일한 것으로 이해한 경우, 북송의 왕안석((王安石)처럼 성리학적 입장에서 현실과 도 원을 낙토(樂土)의 실현으로 동일시하고 실정을 비판하는 경우, 사대부의 학문이나 품성을 확장하기 위한 개인적인 은 
거 공간으로 인식하는 등의 유형이 공존하였다(Choi 2017). 저자의 생각으로는 이 도원에 대한 세가지 의미는 도연명의 원래 도원의 뜻과 함께 안평의 의식/무의식적 소망과 만나 면서 서로 다층적으로 영향을 주고 있다고 판단된다. 우선 여기서 말할 수 있는 것은 아버지 세종이 바랐던-(산관야복 의 사람)이 안내하는-성리학적 이상인 장자 승계를 위해 안 평이 정치 권력에서 멀어져 은자의 몸으로 학문과 품성을 수양하는 의미로 이해된다. 실제로 그는 문종이 즉위한 해인 1450년 9월 이 꿈과 유사한 공간을 발견하여 '무계정사'라는 이름을 지어 그곳에 은거한다. 이에 대한 추가 설명은 '북쪽' 으로 안내한 이유와 함께 뒤에 언급할 것이다.

이제 '산관야복(山冠野服)의 사람'의 무의식적인 의미를 알아본다. 이에 대한 번역으로 $\operatorname{Sim}$ (2018)과 An (2009)은 '산 관야복의 사람'으로 적었고, $\operatorname{Kim}$ (2002)은 의역하여 '소박한 옷을 입은 한 촌부'로 Oh (2020)는 유사하게 '시골 옷차림을 한 사람'으로 말하였다. 야복(野服)의 의미는 '평민이 입는 옷으로 알려져 있지만, 한자 산관(山冠)의 조합은 불명확하 다. 관(冠)은 머리에 쓰는 갓을, 산(山)은 우리가 보고 알고 있는 산이지만, 다의적인 의미의 층이 있다. 꿈에서 단어는 다양한 무의식적 뜻이 압축, 또는 전위되어 나타나는 경우가 많기 때문이다(Freud 1900). 특히 한자는 표의(表意)문자로 그 의미의 중첩과 이동이 더 자유로울 가능성이 있다. 산(山) 의 다양한 뜻을 보면 다음과 같다. ${ }^{f}$

\section{山 (메 산)}

1) 메(산[山]을 예스럽게 이르는 말), 뫼

2) 산신(山神: 산신령), 산(山)의 신(神)

3) 무덤, 분묘(墳墓)

4) 절, 사찰(寺刹)

5) 임금의 상(象)

앞 내용의 맥락으로 이해한다면, 1447년 도원기 꿈에서 한자 山은 '임금의 상(象)'의 의미가 주된 의미이며, '무덤, 분 묘(墳墓)'나 '절, 사찰(寺刹)'의 의미가 내포되어 압축(condensation)되어 있을 가능성이 있다. 앞서 설명했듯이 1447년 2월에 세종은 자신의 죽음과 장례 준비를 하였으며, 안평은 세종의 명으로 소헌왕후가 죽은 후 대자암에서 불사를 그해 두 번이나 지냈고, 세종 역시 생전에 말하기를 자신이 죽은 후 그의 후사(장례 및 제사)까지 대자암에서 행할 것을 아들 에게 명했기 때문이다(Sim 2018). 이런 맥락에서 야복(野服) 의 야(野) 역시 중첩된 의미를 내포한다. 많은 의미 중에 관

${ }^{{ }^{f}}$ 저자는 본 논문 한자에 대한 도움으로 네이버 한자 사전을 인용하 였다. 이 한자사전의 자료는 디지털 한자사전 $\mathrm{e}-$ 사전, 단국대학교 동양학 연구원의 한국한자어 사전, 신동윤의 〈한자로드〉이다.
련된 것을 모아보면 다음과 같다.

\section{野 (들 야)}

1) 들판

2) 민간

3) 문밖, 마을, 시골

4) 야생의

5) 질박하다

6) 촌스럽다. 꾸밈새가 없다.

7) 비천하다 $\cdots$

이러한 이미지는 왕이지만 세종과 어울린다. 세종은 가부 장적인 신분제 사회의 수장이었으나 역대 왕 중 검소한 생 활을 계속했고, 서얼이나 평민, 노비, 여성에게 인간적인 대 접을 해주기 위해 임기 내내 노력했다. 능력이 있으면 서얼 이나 노비라도 관직에 오르게 했으며, 노비는 천민(天民)이 란 말을 종종 하였다고 한다(Han 2019). 이러한 모습을 옆에 서 본 안평에게 이런 인상들이 영향을 주었을 것이라 짐작 할 수 있으며, 안평 역시 그가 왕자의 위치지만 신분에 상관 없이 주변 사람들과 어울렸다고 한다(Kim 2002).

따라서 위 내용을 토대로 '산관야복(山冠野服)의 사람'의 무 의식적인 의미를 종합해보면, 아버지 대상인 세종의 다양한 인상들과 연상들-왕, 죽음, 무덤, 사찰, 소박함, 비천함(노비나 당시 여성의 지위), 농민이나 평민 같음 등-의 압축으로 이해 가 된다. 꿈은 이렇게 담론의 공간에 글로 표현할 수 없는 왕 의 많은 다른 면들을 위 단어에 숨겨 표현할 수 있는 것이다.

이러한 결과를 토대로 해석의 확장을 시도할 수 있다. 꿈 의 ‘단어'에서 아버지 대상과 산(山)의 무의식적 연결은 이미 지로 전위(displacement)되어 표상될 수 있는 것이다. Freud (1900)가 언급한 '일반적으로 꿈은 언어를 사물처럼 다룰 때 가 많고, 그런 경우 사물에 대한 표상처럼 언어를 조합한다' 는 의미는 꿈의 세계에서 이미지와 단어는 무의식적 역동의 논리로 자유롭게 상응한다고 이해할 수 있다. 즉 아버지 대 상의 무의식적 의미가 내포된 '산(山)'이란 단어는 실제 산의 이미지로 위장되어 표현될 수 있는 것이다. 이러한 산과 왕 의 연결을 도와주는 조선시대의 회화가 있다(Figure 5). 일 월오봉도(日月五峯圖)라 일컫는 이 그림은 조선 왕의 권위 를 상징하는 것으로, 이 회화는 왕이 가는 곳이면 반드시 그 뒤에 배치하여 정치적 권위와 위엄을 나타냈다고 한다. 비록 이 전통은 조선 성종 때 첫 기록으로 남아있지만, 그 이전부 터 있을 거라 추정된다(Yu 2013). 오봉도 도상은 한반도 역 사 대대로 내려왔던 음양오행과 산신 신앙에 영향을 받았고, 조선 초기 역시 위 사상의 깊은 영향하에 있었다는 사실은 (Yu 2013), 왕과 산의 무의식적 연결의 근거로 말할 수 있는 


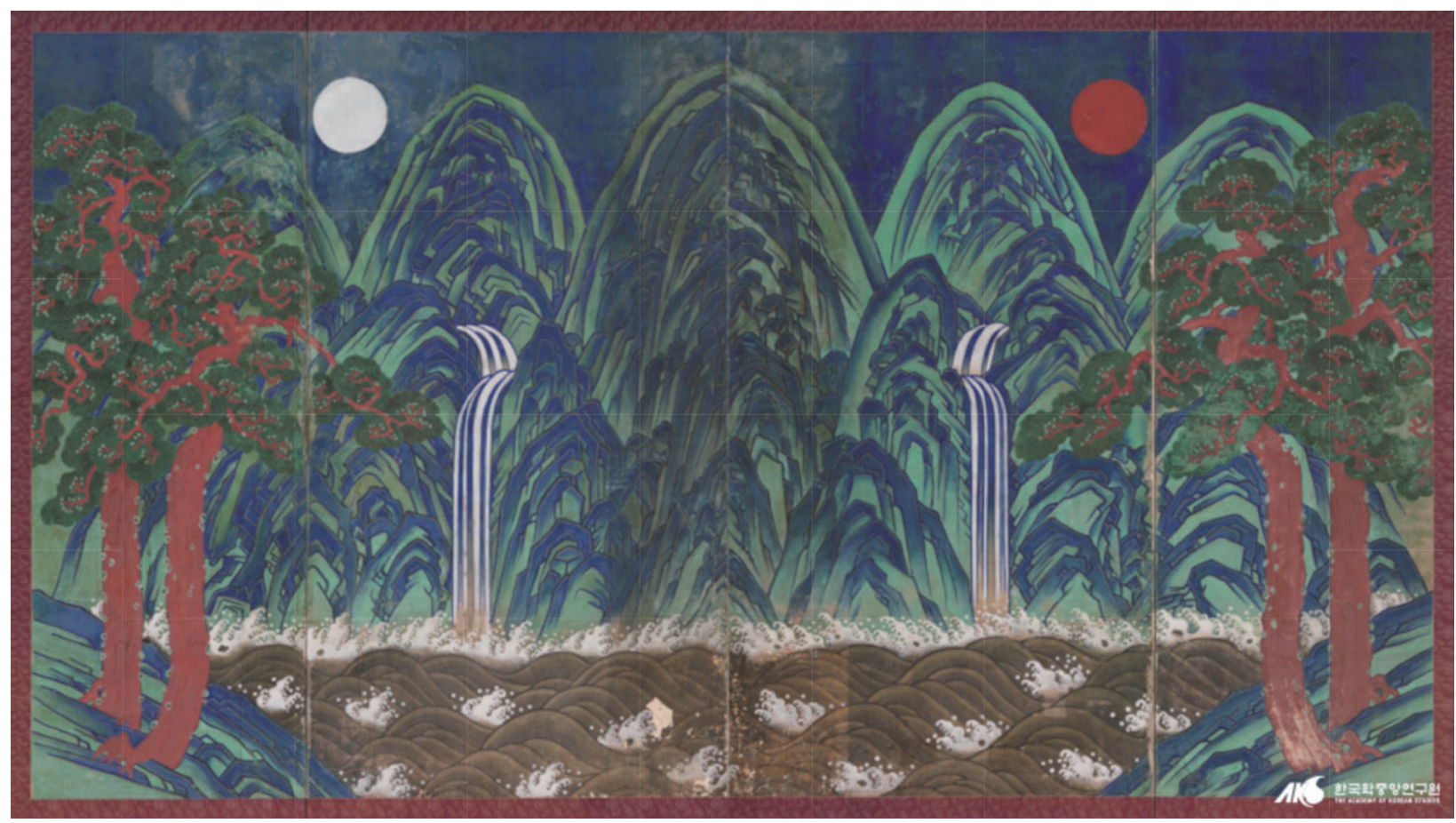

Figure 5. IrwolObongdo (sun, moon, five Peak picture). Late 19th, early 20th century. A four-winded folding screen. $231.3 \times 334 \mathrm{~cm}$.

것이다. 이렇게 대상이 공간으로 느껴지고 표현되는 것에 대 해 저자는 화가 앙리 루소나 프랜시스 베이컨, 또는 소설가 한강 논문에서 밝혔었다(Lee 2019; Lee와 Yoon 2020a; 2020b; 2021a; 2021b).

4

위 내용을 간단하게 정리하면, 안평의 내재화된 아버지 대 상은 발현몽에서 산관야복의 사람과 산의 공간으로 압축과 전위의 방법으로 가장되어 표현되었다는 것이다. 이제 동양 의 이상향으로 알려진 도원이나 복숭아 꽃의 공간에 대한 무 의식적 의미를 알아보고자 한다. 가부장적 사회구조를 구축 했던 조선 시대에서 여성의 위치는 그 존재를 의식적 담론의 공간에서 잘 드러내지 못했다. 이는 아버지 대상보다 무의식 적 어머니 대상은 파생체(deratives)로 의식의 감시에서 벗어 나 두꺼운 가면을 쓰고 있을 가능성이 있다. 하지만 임상의 경험에서 볼 때, 주요 대상은 가면을 쓰되 멀리 있지 않다. 저 자는 본 논문의 주제인 '도원'의 무의식적 의미가 어머니 대 상, 또는 공간이라고 가정한다. 앞서 설명했듯, 도연명의 도 화원기〈인용문 2〉는 중국 역사에서 시대를 지배했던 사상의 담론에 영향을 받아 도교적 신선의 공간, 현실에서의 낙토, 은자의 수양 공간 등으로 조선에 공존했었다(Choi 2017). 이 렇게 시대의 가면을 쓴 도화원의 의미는 비슷한 시대 '복숭 아'에 관련된 설화를 검토함으로써 중층으로 존재하는 무의 식적 의미에 좀 더 접근할 수 있다. 동시대인 중국 동진(東
晉, 4세기) 시기에 간보(干寶)가 엮은 구전 설화집인 수신기 ((搜神記)에서 등장하는 복숭아 관련 이야기는 관념이나 문 학의 가면을 벗겨 좀 더 노골적이고 직접적인 표상을 만날 수 있다. 이 역시 번역된 전문을 싣는다(Gan 2011).

\section{〈인용문 4〉}

유신(劉晨)과 완조(阮肇) 두 사람이 천태산(天台山)으로 곡피를 구하러 들어갔다가, 그만 너무 멀리 들어가 되돌아올 수가 없었 다. 이렇게 13 일을 헤매게 되자, 허기가 져서 견딜 수가 없었다. 그때 멀리 산꼭대기에 복숭아나무가 보였고, 복숭아가 잘 익어 있었다. 두 사람은 칡넝쿨을 잡고 험한 산을 올라, 그 나무에 이 르러 몇 개를 따먹었더니 허기가 그치고 체력이 보충되었다. 이 제 산을 내려가려고 잔으로 물을 떠 마시려는데, 그 물에 무청(無 菁)잎이 떠내려 오는 것이었다. 그 잎은 매우 신선하였다. 다시 뒤이어 잔 하나가 물에 떠내려 왔다. 그 곳에는 참깨가 들어있었 다. 두 사람은 서로 이렇게 말하였다. "이 근처에 사람 사는 집이 있다." 이에 다시 냇물을 따라 산을 넘었더니, 다시 큰 냇물이 나 타났다. 그 냇가에 두 여자가 있었다. 너무나 아름다운 모습이었 다. 그 두 여자는 각기 잔을 하나씩 든 채 웃으면서 문득 이렇게 말하였다. "유신, 완조 두 분께서는 방금 주웠던 그 잔을 돌려주 십시오." 유신과 완조는 깜짝 놀랐다. 두 여자는 다시 즐거운 표 정에 마치 일찍부터 서로 아는 사이인 듯이 말하였다. "어찌 이렇 게 늦게 나타나셨습니까." 이리하여 그들을 모시고 집으로 돌아 갔다. 그 집의 남쪽과 동쪽 두 벽에는 각각 붉은 색 비단 휘장이 
쳐져 있었고, 그 휘장 끝에는 방울이 달려있었으며, 그 꼭대기에 는 금은으로 얽어 장식한 모습이 너무나 아름다웠다. 게다가 그 들은 몇 명의 시녀를 거느려 명령하고 시키고 하는 것이었다. 그 들이 마련한 음식은 참깨 밥, 산양포, 쇠고기 등이었으며, 아주 훌륭하였다. 식사가 마치자 술자리가 펼쳐졌다. 그리고 뒤이어 많 은 여자들이 복숭아를 들고 다가와 웃으면서 축하의 말을 하였 다. "사위로 오신 것을 축하합니다." 뒤이어 술상을 차려 즐거움 을 다하였다. 밤이 되자 각각 하나씩 휘장에 들어가 잠자리를 정 해 주었으며, 여자의 교태가 절륜하였다. 이렇게 열흘이 지나자, 유신과 원조는 돌아가기를 청하였지만, 여자들이 머물기를 고청 하여 다시 반 년을 머물게 되었다. 이윽고 기후를 보았더니 초목 이 모두 봄날이었다. 온갖 새들이 울어, 더욱 고향 생각이 났다. 돌아가고 싶은 마음에 심히 괴로웠다. 여자들은 드디어 그들을 보내 주었다. 손가락으로 돌아가는 길을 가르쳐 주었다. 그들이 되돌아왔더니, 살던 고을은 모두 영락(零落)해 버렸고, 이미 10세 (世)가 흐른 뒤였다.

도화원기〈인용문 2〉와 유사한 내러티브 구조를 지닌 수신 기의 이야기〈인용문 4〉는 몇 가지 특징적인 차이를 보인다. 첫째, 복숭아 나무-도화원기-와 복숭아 열매-수신기-의 차 이다. 이는 도화원기에서는 아름다운 복숭아꽃이 연상되는 감각적인 풍경-“향기로운 풀들 만이 산뜻하고 아름다우며 떨어지는 꽃잎들이 펄펄 날리고 있었다"-을 묘사했고, 수신 기의 주인공은 배고픔으로 복숭아를 먹는 행위 차이를 보인 다. 둘째, 도화원기의 마을은 안정(safety)을 제공하는 정치 적인 피난처로, 수신기의 공간은 식욕과 성욕을 직접적으로 만족시켜주는 퇴행적인 곳으로 묘사되었다. 위 내용을 정리 하면, 주변 설화를 채집한 수신기는 시각적으로 젊은 여성의 젖가슴이 연상되는 '복숭아 열매’를 주요 소재로 하여 식욕 과 성욕의 직접적인 만족을 기술한 반면, 당대 문인의 손을 거친 도화원기는 복숭아 열매를 꽃으로 표현함으로 직접적 인 성욕을 감각적인 환경으로 승화시켰다. 이렇게 직접적인 식욕, 성욕의 만족을 뜻하는 복숭아 열매나, 도피를 위한 피 난처 역할을 의미하는 도화원은 무의식적으로 어머니 대상/ 공간을 의미할 수 있다. 어머니 대상은 위에서 설명한 복숭 아 열매나 꽃으로 상징되는 여러 중층의 표상들을 모두 내 포하고 있기 때문이다(Winnicott 1971).

이러한 맥락을 추가적으로 설명하는 복숭아와 모성과의 관계를 시사하는 중국 신화가 있다. 어머니 대상에 관한 시 대적인 이야기로 짐작되는 서왕모(西王母) 신화는 모계 씨 족 사회나 토템 숭배 시대 등 시대적인 변천을 거쳐 그 모습 이 다양하게 변해왔다(Zhang 2008). 초기 반인반수(牛人牛 獸)의 괴상한 모습에서 동한(東漢) 말기 도교의 영향으로 인
간으로 변했고, 뒤에는 생과 사를 주관하며 불로 장생의 약 을 소유하고 있는 신으로 승격을 하는데, 흥미로운 것은 자 신의 생일인 음력 3월 3일에 불사약인 반도(蟠桃), 즉 복숭아 열매 잔치를 한다는 것이다. 태평성대와 불생불사를 의미하 는 서왕모의 존재와 그녀가 여는 잔치에서 주는 선도(仙桃) 는 이후 중국과 한국의 역사에서 문학이나 예술의 주제로 중요하게 다루어져 왔다(Zhang 2008).

위 내용을 정리하면, 복숭아와 관련된 열매나 도원은 동아 시아 역사에서 무의식적으로 어머니 대상이나 공간을 다층 적으로 표상하는 듯하다. ${ }^{g}$ 따라서 안평대군의 꿈에서 도화원 은 무의식적 계통발생의 흐름에서 끈질기게 살아있는 어머 니 대상/공간을 의미한다. 이 공간을 회화에도 묘사했지만 (Figure 4), 어머니 대상이 있는 동굴, 도원동(桃源洞)으로 말하였다. 흥미롭게도 이 동굴의 신화적 의미를 Cambell (2016)이 생명의 근원인 어머니로의 회귀로 보았고, '여신은 동굴 그 자체와 같다'라고 설명한 점은 위 내용의 또 다른 근 거를 제시한다.

주목해야할 차이점은 도연명의 것이나 이후 중국의 도화 기는 현실 권력의 공간에서 벗어난 분리된 공간-은거나 신 선 등-을 뜻하였는데, 안평의 도원은 아버지를 표상하는 산 의 공간에 공존하고 있는 어머니 대상이 있는 공간인 것이 다(Figure 3). 이는 중국의 것과 다른 한국적 이상향의 차이 로 추가 연구가 필요한 부분인 듯하다.

\section{5}

무의식적 역동의 관점에서 보았을 때, 안평대군이 도원동 에 접근하는 것은 쉽지 않은 일인 듯 하다. 무의식의 세계에 서 아들이 아버지 대상의 시선 아래 어머니 대상을 추구하는 것은 비할 수 없는 갈등과 고통으로 나타난다. 물론 그 접근 과정의 어려움이 꿈의 내러티브나 몽유도원도 회화에서 각 각 표현되었지만, 임상에서 이러한 삼자 관계(triad relation) 는 필연적으로 오이디푸스 갈등을 야기한다. 그 억압된 흔적 을 발현몽이나 회화에서 찾아볼 수 있을까? 저자는 도연명의 도화원기〈인용문 2〉와 구별되는 도원기〈인용문 1〉의 내러티 브에 주목한다. 억압의 흔적은 담론과 차이를 남긴다. 〈인용 문 $1>$ 의 부분이다.

\section{〈인용문 5〉}

\section{$\ldots$ 골짜기에 들어가자 동구가 드넓게 트여서 사방 2,3 리쯤 될}

저자가 간략히 소개한 복숭아를 중심으로 한 여성에 관련한 의미 망들을 정리하면, 생명, 안정감, 성욕, 영원함, 지배성 등이다. 흥미 롭게도 이러한 의미의 망들은 서양의 여신들과 비교해도 그 입고 있는 형식만 다를 뿐이지 내용적으로 유사하다(Cambell 2016). 
듯했다. 사방에는 산이 바람벽처럼 높이 솟아있고 구름과 안개가 자욱한데, 멀고 가까이의 도화 숲이 어리비치어 붉은 아지랑이가 떠올랐다. 또 대나무 숲과 초가집이 있는데, 사립문은 반쯤 닫히 고(柴府半閉), 흙담은 이미 무너졌으며(土砌已沉), 닭과 개와 소 와 말은 없었다. 앞 시내에는 조각배 하나가 물결 따라 오락가락 했다. 그 정경이 소조하여(쓸쓸하여) 선부(신선 거처)와 같았다 $\cdots$.

우선 '휽담은 이미 무너졌으며(土砌已沉)'의 부분을 검토 해 본다. An (2009)과 $\operatorname{Sim}$ (2018), $\operatorname{Kim}$ (2002)은 모두 유사 하게 무너진 흙담으로 해석했고, Oh (2020)는 좀 더 직역으 로 ‘흙 섬돌이 이미 무너졌으며'로 번역을 하였다. 저자가 주 목하는 단어는 체(砌)이다.

\section{砌 (섬돌 체)}

1) 섬돌(집채의 앞뒤에 오르내릴 수 있게 놓은 돌층계)

2) 겹쳐 쌓다.

'섬돌'은 위 설명처럼 낮은 곳에서 높은 곳으로 올라가는 것을 도와주기 위한 중간 단계의 돌로써 보통 마루에 발을 딛기 위한 중간 돌이다. 이는 서양 계단의 동양식 표현이며, Freud (1900)가 언급한 성적 상징으로서의 계단의 의미로 볼 수 있을 듯하다. 또한 이러한 흐름에서 계단은 '성적인 환 상'를 내포하는 의미까지 이어지지 않을까 짐작한다. 이 맥 락으로 보면, 어머니 대상과 연결된 성적인 환상은 자연적으 로 거세의 처벌로 이어질 것이며, 이는 '이미 무너진' 섬돌(土 砌已沉)로 타협될 가능성이 있는 것이다. 또한 체(砌)자가 石 $($ 돌 석 $)+$ 切(끊을 절)과의 조합인데, 거세를 의미할 수 있 는 切(끊을 절), 刀(칼 도)가 함께 있음은 단순한 우연이 아닐 것이다. 여기서 또한 Freud (1900)가 설명한 꿈-형성 과정에 서 단어가 담당하는 다의성의 압축을 말하는 듯하다. 이러한 흐름에서 '사립문은 반쯤 닫히고(柴府半閉)'의 무의식적 의 미를 Freud (1918)가 분석한 늑대 인간의 반복적인 환상인 '열린 창문으로 보이는 다섯 마리의 하얀 늑대'에서 '열린 창 문'이 의미하는 원풍경(primal scene)을 상상하게 한다.

이러한 피분석자에게 확인되지 않은 무의식적 상상력은 언제나 오류의 가능성이 있지만, 꿈의 흐름은 '어머니 대상 과 연관된 금지된 성적인 환상'이 억압되어 있음을 추정하게 한다. 이러한 무의식적 역동의 흔적은 꿈 내용을 그린 회화 에서도 보인다. 꿈에서 자세하게 설명한 내용〈인용문 5>이 회화에서는 전반적으로 작게 뒤에 배치되어 있으며(Figure $1)$, 또한 확대한 그림에서도 〈인용문 5〉의 내용을 정확하게 확인하기 어렵다. 비록 안견이 그림을 그렸지만, 주문자인 안평대군의 요구 사항에 맞춰야 하는 상황에서 이 역동의 흔적은 실제 그림에서도 (피분석자의 언어처럼) '억압'되지
않았을까 한다. 또한 〈인용문 5>에서 '사방에는 산이 바람벽 처럼 높이 솟아있고 구름과 안개가 자욱한데, 멀고 가까이의 도화 숲이 어리비치어 붉은 아지랑이가 떠올랐다'를 충실하 게 구현한 듯한 Figure 4는 위 무의식적 역동이 혼재한 듯한 느낌을 준다. 미술사가인 An (2009)이 '아무 소리도 들리지 않는 적막하고 고요한 분위기가 그러한 형태상의 웅장함과 어우러져 보는 이에게 더욱 기이함을 느끼게 한다'고 서술한 내용은 위 분석의 또 다른 근거를 제공하는 듯하다. 안평대군 의 무의식은 도원의 정서적인 환경(affective environment)을 지향했지만, 한 층 아래 억압된 내용을 의심하게 하는 '기이 함'의 느낌을 동시에 남겨놓아 타협 형성을 하였다.

위 내용을 앞의 분석 결과와 함께 간단히 정리하면 다음 과 같다. 도원은 아버지 대상-세종대왕-의 존재 아래 어머 니 대상이 승화된 형태인 공간이다. 가족 구조(사회 구조)에 서 남자아이에게 이 공존의 조건은 거세지만, 그 구조 안에 서 아버지 대상과 어머니 대상이 부여하는 안정감과 평안함, 만족을 느낄 수 있는 것이다. 안평의 무의식은 자신의 삶의 위기와 전환점의 시기에 어린 시절로 퇴행한 위 역동을 선 택한 것이다. 이는 안평의 이상향, 즉 무의식적 이상화된 공 간이 되었고, 이 공간을 지키기 위해 이후 자신의 삶의 방향 과 가치를 결정한다.

\section{6}

이제 꿈에 등장한 인물들에 대하여 간단히 알아본다. 안평 은 초반에 등장한 인물인 박팽년과 뒤에 나타난 최항, 신숙 주와 함께 자신이 발견한 도원에서 '모두 짚신 감발을 하고 오르내리며 실컷 구경하다가' 꿈에서 깬다. 이 부분에 대한 번역은 대부분 '논다(play)'의 흐름에 있는 듯하다. Oh (2020) 는 '제각기 신발을 가다듬고서 언덕을 오르거니 내려가거니 하면서 두루 살펴보며 즐거워하던 중에'로, $\operatorname{Kim}$ (2002)는 '짚 신 감발(짚신을 신고 발감개를 함)을 하고 들판 주변에 병풍 처럼 둘러선 거산을 오르내리며 대자연에서 마음껏 놀았다' 라고 번역을 하였다. ${ }^{h}$ 이 앞에 이들에 대한 소개로 '함께 찬운 (撰韻)을 하는 자(同撰韻者)'라고 하였는데, 이 의미에 대하 여 An (2009)은 직역으로 '운을 지은 자'로, Oh (2020)은 '평 소에 함께 시를 짓던 사람들'로 번역을 하였다. $\operatorname{Sim}$ (2018)은 좀더 자세히 접근하여 ‘찬운(撰韻)'이 당시 한자음에 우리의 음을 표기한 '동국정운'의 편찬을 의미한다고 하였다. 이는

h등장한 인물의 순서에 의미를 부여하기도 하였는데 먼저 등장한 박팽년은 후에 단종복귀운동 때에 사육신으로 죽음으로써 충의를 보였지만, 뒤의 인물 두명은 계유정란 때에 안평과 길을 달리한 이 들이다. 이를 안평이 미리 꿈에서 예지하여 순서를 예견하였다고 말하나 이는 알 수 없는 일이다. 
도원기〈인용문 1〉에서 말했듯, '궁중에 몸을 담아 밤낮으로 하는 일'의 시기로, 훈민정음의 출간 이후 동국정운의 편찬 작업이 절정에 이른 시기이다( $\operatorname{Sim} 2018)$. 따라서 위 내용은 '동국정운을 편찬하는 3명과 함께 도원에서 노닐다'로 정리 할 수 있다.

정신분석의 관점에서 위 내용을 도원과 결합하면 어머니 대상의 정서적인 환경 (affective environment)에서 '놀이 (play)'라는 의미가 있다. 이는 현실과 비현실, 내면 세계와 외부 세계 사이의 가상 공간으로, Winnicott (1971)이 말한 어머니 대상과 연결된 이행 공간(transitional space)의 가능 성이 내포되어 있다. 이 공간에서의 놀이는 존재(being) 경험 의 기초와 창조성, 그리고 문화 경험을 제공한다(Winnicott 1971). 당시 힘의 불균형의 시대에 중국 문화를 그대로 받아 들여야 하는 시기, 그 문화의 핵심인 당시 문자 언어인 한자 에 한글의 음을 표기하는 행위는 타자화된 문화 정체성의 구 분을 의미하는 행위일 수도 있는 것이다. 이미 3명은 시(詩) 로 서로 노는(play) 사이로 몽유도원도 21 명의 찬시에 이름 을 올렸다는 점 역시 의미가 있다고 본다.

\section{7}

이제 앞의 분석 내용과 종합하여 안평대군의 꿈-사고를 정리할 수 있다. 저자가 주장하는 안평의 발현몽에 대한 꿈사고, 즉 잠재몽은 "안평대군은 어머니 대상이 함께 하는 아 버지 대상의 세계를 소망하는 것”이다. 이런 평범해 보일 수 있는 꿈의 소망이 특별해지는 것은 안평의 아버지가 지금도 많은 한국인들이 이상적 대상으로 여기고 있는 세종대왕이 기 때문이다. 이런 맥락에서 세종이 죽기 전 안평대군의 현 실은 도원기의 꿈과 다르지 않았다. $\operatorname{Sim}$ (2018)이 안평대군 에 대해 몽유(夢遊)의 삶이라고 말을 한 이유가 있는 것이다. 단지 그가 꿈을 꾸던 시기 그의 '꿈과 같은 현실'이 위협을 받았던 것이다. 앞서 말했듯 어머니 소헌왕후의 죽음, 그리 고 아버지 세종의 죽음이 임박했고 그의 형인 병약한 문종 의 상황은 그의 꿈같은 현실이 무너지는 위기였던 것이다. 따라서 첫 꿈을 꾼 이후에도 계속 도원기의 무의식적 소망 은 백일몽으로 현실에 나타난 것으로 예상할 수 있다.

정신분석의 임상에서 확인하듯 분석되지 않은 무의식-꿈, 증상, 전이 등-은 삶에서 반복된다. 따라서 꿈 이후 안평대 군의 삶의 추적은 저자의 꿈 분석 내용에 대한 또 다른 근거 로 제시될 수 있을 것이다.

안평의 무의식적 소망, 즉 이상향은 가부장의 사회 구조에 서 아버지 세종의 시대를 유지하고 지키는 것으로 구체화된 다. 이는 그의 삶에 뚜렷한 지향점을 형성하여 그 가치를 실 현하려 한다. 아버지 세종이 죽고, 문종이 즉위한 후 7개월
뒤인 1450년 9월 그는 현재 북악산 서북쪽에서 실제 그가 1447년 꾸었던 꿈의 공간을 발견한다. 꿈으로 보였고, 수년 간 백일몽으로 눈에 선했던 도원이 현실로 나타난 것이다. 안평대군은 여기에 무계정사(武溪精舍)-현재 서울 종로구 부암동-를 짓고 거주한다. ${ }^{i}$ 이 공간의 발견에 대하여 학자들 의 의견은 풍수지리적 관점이 주를 이루는 듯하다. 실제 세 종뿐만 아니라 그의 아들들은 삶의 위기 때에 불교나 풍수 지리설에 의존했었다(Kim 2002). 세종의 죽음과 병약한 문 종의 즉위 상황에서 풍수나 불교는 안평대군에게 깊은 영향 을 미쳤다. 당시 풍수지리자인 이현로(李賢老)는 “백악산현재 북악산-뒤에 궁을 짓지 아니하면 정룡(正龍)이 반드시 쇠하고, 방룡(傍龍)이 반드시 일어날 것이다”라는 풍수설을 소개하며, 백악산 뒤에 궁을 지을 것을 주청했고, 문종은 수 양대군과 안평대군에게 이러한 설을 조사해보라고 했다고 한다(Kim 2002). 정룡은 큰아들인 문종을 의미하고, 방룡은 차자를 의미하는 이 풍수설은 세종이 그토록 이루려 했던 적장자 승계에서 벗어난 것으로, 세자인 단종의 위치까지 위 협하는 것이다. 따라서 이러한 풍수설에 영향을 받아 북악산 뒤에 있는 무계정사의 위치를 (의식적으로) 결정했다고 보 는 것이다(Kim 2002; Cho 2015). 이것이 정치적인 의미가 있는지, 그가 적은 글처럼 우연한 발견과 선택인지 정확히 알 수 없다. 하지만 정치적 의미인 풍수설의 영향이든 우연 한 발견이든 모두 꿈의 잠재몽처럼 아버지 세계를 소망한다 는 점은 변하지 않는다. 임상에서 흔히 보는 것처럼 무의식 적 소망은 시대 사상이나 관념, 이야기와 결합하여 은밀하게

i안평대군은 그가 해왔던 대로 무계정사를 열고 자신의 행위에 대 하여 시로 남겼다. 소개 글을 번역한 한글로 보면 다음과 같다(Kim 2002).

나는 정묘년(1447년) 4월에 도원 꿈을 꾸었다. 작년(1450년) 9월에 우연히 이곳을 유람하다가 국화꽃이 계곡물에 떠내려오는 것을 보고, 다래 넝쿨과 바위를 부여잡고 계곡을 올라가서 보니, 풀과 나무와 물가의 그윽한 모습이 내가 꿈에 본 도원의 모습과 흡사했다. 그래서 금년(1451년) 이곳에 서너 칸 의 집을 짓고 무릉계곡의 뜻을 취하여 '무계정사라 했다. 이곳은 신실로 정 신을 편안케 하는 은자의 땅이로다. 이에 잡영시 다섯 편을 지어 찾아와 묻 는 자들에게 대비하고자 한다.

경태 2년(1451) 7월 21일 천석주인(泉石主人) 낭간거사(琅玕居士) 청지(淸之).

무계정사에 대한 이 소개 글에서 천석주인(泉石主人)이란 새로운 호가 등장하는데, 이는 '자연의 주인'이라는 뜻이다(Kim 2002). 또 한 윗글 아래 내용 중 '이곳은 신실로 정신을 편안케 하는 은자의 땅이로다. 이에 잡영시 다섯 편을 지어 찾아와 묻는 자들에게 대비 하고자 한다'에서 자신을 은자로 표현하고, 이 공간에 대한 글을 지 어 의문의 여지가 없이 하겠다는 의미는 자신이 (아버지 세종의 뜻대 로) 정치에서 벗어나 자신이 원했던 공간에서 자연인으로 살겠다는 의지의 표현으로 이해된다. 
그 소망을 이루기 때문이다.

이 무계정사에서의 삶은 (아버지 세종의 뜻과 다르게) 다 음 해 봄 문종의 병이 악화되었다는 이야기를 듣고 막을 내 리는 듯하다. 그는 칩거 기간 중 대자암(大慈庵)에서 세종의 천도(薦度)를 위한 성대한 불사와 안거회(安居會)를 주관했 으며, 그가 사재를 내어 중창하고 불상을 주조한 충청도 복 천사(福泉寺)에서 다시 세종의 천도를 위한 수륙제(水陸齋) 를 올렸다(Kim 2002). 이런 안평대군의 삶은 비록 그가 꿈꾸 었던 공간에서 벗어났으나 여전히 그의 이상향인 아버지 세 종의 세계를 추구하고 있음을 의미한다. ${ }^{j}$ 이제 그의 꿈 〈인용 문 1>에서 산관야복의 사람이 지시한 방향이 북쪽인지 짐작 할 수 있다. 앞서 언급했듯(Sim 2018), 꿈을 꾸기 전 소헌 왕 후 사후 불사를 지냈었고, 세종 역시 자신이 죽은 후 그의 장 례를 아들에게 명한 대자암의 위치가 그가 꿈을 꾸었던 비 해당에서 북쪽 방향이다. ${ }^{k}$ 이렇게 안평이 어머니와 아버지 의 극락왕생을 빌었던/빌 곳인 대자암은 그의 무의식적 소 망의 공간과 지리적으로 평행하는 것이다. 또한 무계정사 역 시 비해당에서 북쪽 방향임을 볼 때, 위에서 말했듯 비록 장 소 선정이 정치적인 이유가 짐작되더라도 무의식적 소망이 또 다른 층위에서 영향을 주었을 것이라 예상할 수 있다.

\section{8}

이제 위 분석 내용이 몽유도원도 회화의 양식에 어떤 영 향을 주었는지 간략하게 설명하고자 한다. 사실 한국뿐만 아 니라 동아시아 미술사에서 중요한 위치에 있는 만큼 미술사 적인 방대한 연구의 흐름을 여기에 전부 적을 수 없다. ${ }^{1}$ 이에 저자는 서문에서 언급한 몽유도원도만의 독특한 양식-회화 에 사람이 없는 것과 회화에서 이야기의 진행 방식-을 꿈 해

${ }^{\mathrm{j}} 1452$ 년 5월 14일 문종은 죽자, 안평대군의 삶은 앞서 언급한대로 그의 형인 수양대군의 권력에 희생양이 되어 1453년 9월 계유정란 때 모반이라는 죄목으로 강화도 교동도에서 사사된다. 그의 남은 형제의 삶의 지향점 역시 안평대군과 유사하다. 여섯째 아들 금성 대군은 사육신 사건이 일어난 직후 단종 복귀를 도모하기 위해 유 배지에서 군사를 모으다가 발각되어 사사되었고, 막내 영웅 대군 은 34세 병사했으며, 가장 늦게까지 생존한 넷째 아들 임영대군은 51세에 임종 시 "나는 안평 형님과 금성 아우를 따라 절의에 죽으 려 했으나 그러지 못했다”라는 말을 남긴 것으로 후손에게 전해진 다(Kim 2002).

${ }^{k}$ 비해당의 현재 주소는 서울 종로구 옥인동 수성동 계곡 근처로 알 려 져있다. 대자암의 현 주소는 경기도 고양시 대자산 근처로 알려 져 있다. 무계정사의 현 주소는 종로구 부암동 329번지 부근이다. 1동아시아 미술사는 중국의 영향에서 벗어날 수 없다. 몽유도원도 역시 안견이 당시 유행하고 있는 중국 회화의 다양한 양식을 흡수 해 자신만의 독특한 양식을 이루었다. 이에 대한 자세하고 종합적 인 설명은 An (2009)의 설명을 참조하면 된다.
석을 기반으로 설명하려 한다.

저자가 해석한 안평대군의 꿈 내용은 '어머니 대상이 함께 하는 아버지 대상의 세계를 소망하는 것'이고, 이 이상적 공 간은 그가 현실에서 살았던 삶이었으며, 꿈은 그 현실이 좌 절되려는 시기에 나타난 것으로 이해했다. 또한 그는 그 이 상적 공간을 다시 현실에 구현하려고 노력했다. 어쩌면 그는 (무의식적) 이상과 현실이 교차하고 혼재된 삶을 살았던 것 같다. 그에게 이상적 공간-도원-은 현실과 겹쳐져 있다. 이 러한 사실은 몽유도원도에 사람이 없는 이유를 설명한다. 몽 유도원도는 꿈의 산관야복의 사람과 세 명의 사람을 경험했 던 꿈을 꾸었던 과거를 그린 것이 아니라, 여전히 현실이라 믿고 싶은 진행형의 꿈을 구현한 회화인 것이다. 즉, 그는 아 마도 두루마리를 펼쳤을 때, 여전히 도원의 꿈을 현재라고 믿고 싶었던 것 같다.

이러한 맥락에서 몽유도원도만의 독특한 이야기 진행 방 향(Figure 2)을 생각할 수 있다. ${ }^{\mathrm{m}}$ 두루마리를 펼쳤을 때 안평 대군은 전통의 그림처럼 과거의 이야기를 확인하는 것이 아 닌 것 같다. 여전히 아른거리는 도원의 백일몽이 그에게 이 야기의 시작이고, 그 인상으로부터 역으로 꿈을 꾸었던 이야 기가 진행되기 바랐는지 모른다. '무의식의 현재성'은 정신 분석에서 과거 고착된 무의식적 환상/꿈의 반복인 전이 (transference)로, 증상으로 나타난다. 안평대군에게 이 겹쳐 진 과거와 현재의 소망이 진행하는 시간에도 여전히 존재하 기를 소망하지 않았을까 짐작해본다. 저자의 설명은 관점의 차이는 있지만, $\mathrm{Oh}$ (2020)의 직관적인 설명과 함께 한다. 몽 유도원도의 현실경-(Figure 3)에서 1군-보다 꿈속의 경관 (Figure 4)이 더 진하고 분명하다. 이에 대한 이유가 꿈속 도 화원의 장면을 회화의 강조점을 두고 '꿈이 막 깨려는 순간 의 인상'부터 (꿈 내러티브의 역순으로) 그린 것이라는 설명 이다(Oh 2020).

이러한 경험과 내용(contents)이 추동하는 기존 양식의 균 열과 변화는 미술사의 흐름에서 확인되며, 저자의 몇몇 논문 에서도 개별적인 무의식적 요소가 양식에 어떤 영향을 주는 지 설명하였다(Lee와 Yoon 2021a; 2021b; 2021c). 흥미로운 점은 예술 뿐만 아니라 음악, 농업, 과학, 정치 등 대부분의 분야에서 위와 같이 현실 경험이 기반이 된 정체성의 움직 임이 세종 시대에 편재해 있었다는 사실이다(Han 2019). 훈 민정음의 반포는 상징적인 것일 뿐이다.

m이에 대한 미술사적인 연결의 시도가 있지만 여전히 설명돼야 할 부분이 있다. 이에 대한 자세한 설명은 An (2009)과 Cho (2015)를 참조하면 된다. 


\section{결 론}

본 논문은 우리나라 회화사에서 가장 중요한 위치에 있는 몽유도원도(夢遊桃源圖)의 주인공인 안평대군의 꿈을 정신 분석학적인 방법으로 접근한 첫 번째 논문이다. 중국 진(亞) 나라의 대표적인 시인 도연명(陶淵明)의 도화원기(桃花源記) 를 기본 틀로 하는 안평대군의 도원기(桃源記)의 내용을 분 석한 결과는 "안평대군은 어머니 대상이 함께하는 아버지 대 상의 세계를 소망하는 것”이다. 저자는 안평대군을 도원으로 이끌었던 '산관야복(山冠野服)의 사람'과 '산의 공간'이 무의 식적으로 변형된 아버지 대상임을, '도화원의 공간'을 어머니 대상을 표상하는 정서적 환경(affective environment)이라고 설명하였다. 이러한 무의식적 삼자 관계(triad relation)에서 '사립문은 반쯤 닫히고(柴扁牛閉), 흙담은 이미 무너졌으며 (土砌已沉)'의 문장과 단어에 성적인 환상 및 거세의 흔적을 남긴 것으로 분석하였다. 도원에서 뛰어논(play) 세 명의 사 람에 대한 무의식적 의미는 어머니 대상의 정서적인 환경에 서의 '놀이'이며, 이는 Winnicott (1971)의 이행 공간(transitional space)의 가능성을 말하였다.

안평대군의 위 이상향은 아버지인 세종대왕의 시대가 저 무는 시기에 반복적으로 출몰한 무의식적 환상이며, 그의 삶 의 지향점은 아버지의 뜻을 이어 아버지가 원하는 장자 승 계를 지키는 것으로 구체화된다. 병약한 문종의 즉위는 당시 장자 승계를 주장한 풍수지리설에 영향을 받아 꿈의 이상향 과 비슷한 무계정사(武溪精舍)를 지어 현실 속의 도원을 만 들었으며, 문종의 죽음 후 그는 무계정사에서 나와 (아버지 세종의 뜻인) 단종을 지키려고 했다. 이는 분석되지 않은 꿈 이 삶에서 반복되는 예일 것이다.

이 논문은 여러 한계가 있다. 첫째, 분석되지 않은 부분이 여전히 많이 남아있다. 하지만 실제 임상에서 꿈의 모든 부 분은 분석되지 않고 중요한 흐름을 전이나 증상, 또는 피분 석자의 삶과 연결시키는 것처럼, 저자는 제한된 상황에서 안 평의 꿈을 분석하였다. 그리고 대부분의 꿈 분석에서 그렇듯 하나의 꿈의 층위로는 잠재된 내용을 전부 알 수가 없다. 피 분석자가 그 억압된 흔적을 모호한 문장이나 단어로 남기 듯, 안평 역시 그럴 수가 있는 것이다. 둘째, 시대와 문화와 의 차이다. 한자문화권, 시대적인 사상이나 종교, 관념 등의 차이는 전반적인 꿈의 분석에 오류의 가능성이 있다. 이는 앞으로의 추가 연구로 보완되어야 할 사항이다. 셋째, 저자 는 조선 초기 꿈에 대한 인식을 거의 다루지 못했다. 안평은 도원기의 끝 부분에서 말한 '낮에 한 일이 밤에 꿈이 된다'는 말은 Freud (1900)의 연구 결과와 유사하지만, 전반적인 인 식은 무척 차이가 있다. 당시 꿈에 대한 인식에 대하여는
Kim (2002)에 잘 정리되어 있다. 넷째, 몽유도원도의 이해에 대한 다양한 관점들을 다루지 못했다. 저자는 당시 성리학이 나 불교, 풍수지리설이 무의식의 옷을 입고 안평의 삶에 은 밀하게 영향을 주는지 간단히 알아보았으나 부족한 부분이 많다. 시대적인 사상이나 관념, 종교와 무의식과의 관계는 흥미로운 부분으로 많은 추가 연구가 필요한 듯하다.

이러한 제한점에도 본 논문은 의미가 있다. 첫째, 안평대 군의 이상향은 도연명의 도화원기와 다른 한국적인 이상향 을 추구한다. 그가 지키고자 했던 이상적인 공간은 다름 아 닌 현대의 한국인에도 이상적 대상인 세종대왕의 정치 공간 이다. 비록 안평대군의 삶은 비극적으로 끝났지만 그가 꿈꾸 던 세상은 지금도 세종대왕의 동상이 광화문의 한복판에 있 는 것처럼 (의식/무의식적으로) 진행형인 것이다. 둘째, 미 술사적 관점에서의 의의다. 저자의 꿈 분석을 토대로 몽유도 원도의 독특한 양식인 사람이 없는 것과 전통과는 다른 이 야기 진행 방식에 대한 가설적 설명을 하였다. 이런 양식사 적인 설명과 무의식적 정신(psyche)을 담고 있는 몽유도원 도가 비록 수백 년 동안 숨어있었지만, 그 정신은 미술사가 아비 바르부르크(Aby Warburg)가 말한 것처럼, 다양한 양 식으로 유령(ghost)처럼 출몰할 수 있는 것이다(Didi-HuBerman 2017). 이에 대한 미술사적인 추가 연구가 필요할 것이다.

저자는 잔인한 정변으로 인해 삶을 마감한 조선 시대 한 왕자의 꿈과 회화를 분석하였다. 하지만 그가 꾸었고 삶에서 추동했던 이상적 대상이나 공간은 바로 놀라운 천재성과 애 민 정신의 결과물인 한글을 우리에게 제공했던 세종대왕이 었다. 비록 비극으로 끝난 꿈과 삶이었지만, 그의 꿈은 우리 에게 살아있는 화석처럼 '아직도 살아있는 꿈’이 아닐까 짐 작해본다. 저자는 위 내용들을 지지하는 Freud의 글을 적음 으로써 본 논문을 마치려고 한다(Freud 1900).

...꿈은 소망을 성취된 것으로 보여주면서 우리를 미래로 인도한다. 그러나 꿈을 꾸는 사람이 현재의 것으로 받아들이 는 미래는 소멸될 수 없는 소망에 의해 과거와 닮은 모습으 로 형성된다...

\section{Acknowledgments}

None

\section{Conflicts of Interest}

The authors have no potential conflicts of interest to disclose.

\section{Author Contributions}

Conceptualization: all authors. Investigation: Lee Hyun Kwon. Methodology: Lee Hyun Kwon. Project administration: Lee Hyun Kwon. Writing — original draft: Lee Hyun Kwon. Writing — review \& editing: all authors. 


\section{ORCID iD}

Hyun Kwon Lee https://orcid.org/0000-0002-6193-2552

\section{REFERENCES}

An HJ. An Gyeon and a Dream Journey to the Peach Blossom Land. Seoul: SapyoungBook;2009. p.4-179.

Cambell J. Goddesses: mysteries of the feminine divine. Gu HS, translator. Paju: Chungabook;2016. p.4-444.

Cho KH. Prince Anpyeong and his auspicious-omen painting: an Gyeon's Dream Journey to the Peach Blossom Land. Art Hist Vis Cult 2015; 16:6-33.

Choi KH. Joseon period peach blossom land painting and modern changes in their expression. Korean Stud Q 2017;40:35-68.

Didi-HuBerman G. The surviving image: phantoms of time and time of phantoms: Aby Warburg's history of art. Mendelsohn HL, translator. University Park, PA: The Pennsylvania State University Press;2017. p.1-66.

Freud S. The standard edition of the complete psychological works of Sigmund Freud/4: the interpretation of dreams. P. 1. London: Hogarth press;1900. p.1-626.

Freud S. From the history of an infantile neurosis. SE 17. London: Hogarth press;1918. p.1-124.

Freud S. Leonardo da Vinci and a memory of his childhood. In: Strachey J, translator. The standard edition of the complete psychological works of Sigmund Freud. Vol. 11 (1910): five lectures on psycho-analysis, Leonardo da Vinci, and other works. London: Hogarth Press;1957. p.59-138.

Gan B. Sou Shen Ji 3/3. Lim DS, translator. Seoul: DongSuhbooks; 2011. p.1419-1421.

Han YU. Critical Biology of SeJong. Paju: Kyongseaewon;2019. p.13-
860.

Kim KY. Find the missing a Dream Journey to the Peach Blossom Land Islands. Seoul: Sanbooks;2002. p.5-386.

Lee HK. Preliminary study for the artist Francis Bacon in the perspective of the unconscious. Psychoanal 2019;30:32-39.

Lee HK, Yoon HR. Study for novelist Han Kang's short story ${ }^{\ulcorner}$My Woman's Fruit $\lrcorner$ in the perspective of the unconscious: with other short stories at that time. Psychoanal 2020a;31:52-61.

Lee HK, Yoon HR. Study for novelist Han Kang's story "The Vegetarian" in the perspective of the unconscious. Psychoanal 2020b;31:8190.

Lee HK, Yoon HR. Study for artist Henri Rousseau in the perspective of the unconscious: centering on his jungle series. Psychoanal 2021a;32: 21-35.

Lee HK, Yoon HR. Study for Artist Henri Rousseau in the perspective of the unconscious: centering on his landscapes, figures, still-life paintings. Psychoanal 2021b;32:52-63.

Lee HK, Yoon HR. Study for Odilon Redon in the perspective of the unconscious: centering on before his black series. Psychoanal 2021c;32: 89-106

Oh JS. The pleasure of reading old paintings 1. Seongnam: Shingubook; 2020. p.54-76.

Sim KH. An Pyeong. Seoul: Almabooks;2018. p.7-1125.

Yu HJ. A study on the screen of sun, moon and five peaks in the Joseon dynasty [dissertation]. Seoul: Graduate school of Sungkyunkwan University;2013. p.71.

Winnicott DW. Playing and reality. London: Tavistock Publication;1971. p.1-156.

Zhang R. The acceptance aspect of South Korea culture by SeoWangmo [dissertation]. Daegu: Daegu University;2008. p.43. 